Government and Politics of the United States 


\section{COMPARATIVE GOVERNMENT AND POLITICS}

\section{Series Editor: Vincent Wright}

\section{Published}

Rudy Andeweg and Galen A. Irwin

Dutch Government and Politics

Nigel Bowles

Govermment and Politics of the United States (2nd edition)

Paul Brooker

Non-Democratic Regimes: Theory, Government and Politlas

Robert Elgie

Polltical Leadership in Lberal Democrecles

Rod Hague and Martin Harrop

Comparative Government and Polltics (5th edition)

Paul Heywood

The Govemment and Politics of Spain

\section{B. Guy Peters}

Comparative Politics: Theorles and Methods

Tony Saich

Covermance and Polltics of China

\section{Anne Stevens}

The Covernment and Politics of France (2nd edition)

Ramesh Thakur

The Government and Politics of india

Forthcoming

Judy Batt

Government and Politics in Eastern Europe

Robert Leonardi

Government and Politics in Italy

\section{Comparative Government and Politics}

Series Standing Order

ISBN 978-0-333-71693-9 hardcover

ISBN 978-0-333-69335-3 paperback

(outside North America only)

You can receive future titles in this series as they are published by placing a standing order. Please contact your bookseller or, in the case of difficulty, write to us at the address below with your name and address, the title of the series and the ISBN quoted above.

Customer Services Department, Macmillan Distribution Ltd Houndmills, Basingstoke, Hampshire RG21 6XS, England 


\title{
Government and Politics of the United States
}

\author{
Second Edition
}

Nigel Bowles

palgrave 


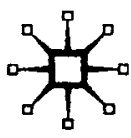

(C) Nigel Bowles 1993, 1998

All rights reserved. No reproduction, copy or transmission of this publication may be made without written permission.

No paragraph of this publication may be reproduced, copied or transmitted save with written permission or in accordance with the provisions of the Copyright, Designs and Patents Act 1988, or under the terms of any licence permitting limited copying issued by the Copyright Licensing Agency, 90 Tottenham Court Road, London W1T 4LP.

Any person who does any unauthorised act in relation to this publication may be liable to criminal prosecution and civil claims for damages.

The author has asserted his right to be identified as the author of this work in accordance with the Copyright, Designs and Patents Act 1988.

First edition 1993

Reprinted twice

Second edition 1998

Published by

PALGRAVE

Houndmills, Basingstoke, Hampshire RG21 6XS and 175 Fifth Avenue, New York, N. Y. 10010

Companies and representatives throughout the world

PALGRAVE is the new global academic imprint of

St. Martin's Press LLC Scholarly and Reference Division and Palgrave Publishers Ltd (formerly Macmillan Press Ltd).

ISBN 978-0-333-69486-2 ISBN 978-1-349-26454-4 (eBook)

DOI 10.1007/978-1-349-26454-4

This book is printed on paper suitable for recycling and made from fully managed and sustained forest sources.

A catalogue record for this book is available from the British Library.

Transferred to digital printing 2002

Copy-edited and typeset by Povey-Edmondson Tavistock and Rochdale, England 
Dedicated to the memory of Colin Moss

1954-1996

friend and scholar 


\section{Contents}

List of Tables, Figures, Exhibits and Maps $\quad \mathrm{x}$

Preface to the Second Edition xiii

Preface to the First Edition and Acknowledgements xv

The United States: State Boundaries and Major Cities xviii-xix

1 Introduction 1

Political values and society 1

The Articles of Confederation $\quad 10$

The Constitutional Convention and ratification 11

Separated institutions and shared government 14

2 Political Parties: The Politics of Aggregation and Disaggregation 18

Party and the culture of American politics 18

The development of the American two-party system 21

Party politics in the South $\quad 32$

American political parties as quasi-public institutions $\quad 35$

Party organization $\quad 39$

The bipolar American party system 43

Weakness of American political parties $\quad 46$

$\begin{array}{ll}\text { Conclusion } & 48\end{array}$

3 Elections and the Politics of Participation 50

Who has been able to vote? $\quad 50$

Who exercises the right to vote, and who abstains? 60

How Americans run for election and vote 62

For whom do Americans vote? 82

Conclusion $\quad 96$

4 The Presidency and the Politics of Leadership 98

Presidential leadership $\quad 98$

Prerogative powers of the Presidency 100

Inherent powers of the Presidency 101

The Presidency and the mass media 104

The Vice-Presidency 106

Franklin Roosevelt, Harry Truman, and the modern Presidency 108

$\begin{array}{ll}\text { The obligation to bargain } & 110\end{array}$ 
The Presidency and the Executive Branch 111

The Presidency and Congress 128

Conclusion 133

5 Congress and the Politics of Legislative Competition 135

Procedural and structural dimensions $\quad 135$

$\begin{array}{ll}\text { The bicameral dimension } & 136\end{array}$

The institutional dimension 138

The individual dimension $\quad 141$

The specialised and fissiparous dimension 145

$\begin{array}{lr}\text { The aggregative and collective dimension } & 159\end{array}$

Party Organization in the House 162

Party Organization in the Senate 166

Party and Voting 169

Caucuses $\quad 171$

$\begin{array}{ll}\text { The procedural dimension } & 172\end{array}$

Legislation in the House $\quad 174$

Legislation in the Senate $\quad 177$

$\begin{array}{ll}\text { Conference Commitees } & 179\end{array}$

$\begin{array}{ll}\text { Conclusion } & 179\end{array}$

6 The Supreme Court and the Politics of Adjudication 181

The organization and role of the judiciary 181

The Supreme Court's jurisdiction 187

$\begin{array}{ll}\text { Procedure } & 190\end{array}$

Judicial review 196

The Supreme Court and the Elected Branches 200

Chief Justices and leadership of the Court 213

Enforcement of desegregation $\quad 216$

Conclusion 220

7 Interest Groups $\quad \mathbf{2 2 0}$

Accountability and the allocation of political power $\quad 220$

The interest industry 223

Interest representation, institutional openness, and policy-making 225

Congress 228

Participants in the interest industry 238

Conclusion $\quad 249$

8 Bureaucracy: The Fourth Branch of Government 250

The Federal civil service 251

Federal regulation $\quad 257$

Bureaucratic structure and organization 262 
Administrative law $\quad 266$

Congressional control of the bureaucracy 268

$\begin{array}{ll}\text { Conclusion } & 275\end{array}$

9 Federalism and Intergovernmental Policy-Making 277

Federalism: theory and structure $\quad 277$

The development of the constitutional law of federalism 284

Federalism: structure and process of intergovernmental fiscal $\begin{array}{ll}\text { and policy relations } & 296\end{array}$

$\begin{array}{ll}\text { Conclusion } & 317\end{array}$

10 The Politics of Cities and Suburbs 319

$\begin{array}{ll}\text { The subject } & 319\end{array}$

Intellectual importance of cities and suburbs 323

Declining, diverse, and dynamic cities: different fiscal fates $\quad 330$

Three faces of metropolitan politics: suburbanization; race and ethnicity; and poverty $\quad 335$

$\begin{array}{ll}\text { Conclusion } & 347\end{array}$

11 Domestic Economic Policy 348

$\begin{array}{ll}\text { The economic policy process } & 348\end{array}$

Participants in economic policy-making $\quad 351$

The Federal Reserve Board and the Federal Reserve Banks 355

Objects and processes of economic policy-making 361

$\begin{array}{ll}\text { Monetary policy } & 375\end{array}$

$\begin{array}{ll}\text { Conclusion } & 380\end{array}$

12 Foreign and Defence Policy 381

Foreign policy, defence policy, and the national interest 381

$\begin{array}{ll}\text { Institutional participants } & 382\end{array}$

Processes of foreign and defence policy-making 403

$\begin{array}{ll}\text { Conclusion } & 414\end{array}$

13 Conclusion $\quad \mathbf{4 1 6}$

Appendix 1: The Constitution of the United States 421

Appendix 2: Amendments to the Constitution of the United States 429

Appendix 3: Constitutional Allocation of Powers over Foreign and Defence Policy 436

$\begin{array}{ll}\text { Further Reading } & 438\end{array}$

Bibliography 446

Index $\quad 455$ 


\section{List of Tables, Figures, Exhibits and Maps}

\section{Tables}

2.1 Party and delegation to Congress, January 1963 and January 1997

3.1 Amendments to the Constitution concerned with electoral rules

3.2 Presidential vote by social groups

5.1 Party balances in Congress, 1929-97

8.1 Executive level civilian federal appointments

9.1 Revenues and expenditure of Federal, State and local governments, 1927-44

9.2 Local government revenue, by source before and during the New Deal

9.3 State government revenue, by source, before and during the New Deal

9.4 Federal intergovernmental grant-in-aid (GIA) to State and local governments by function from before the New Deal to the close of the Great Society, 1930-70

9.5 Federal grants in aid, 1970-95

10.1 Highest population rates of growth and decline by county, 1980-92

10.2 City governments - ten largest cities' revenue and debt, 1992

10.3 Largest cities' Finances, 1992

10.4 Educational attainment by race and ethnicity, 1960-94

11.1 Outlays by Budget Enforcement Act categories, 1962-98

11.2 Revenues, outlays, deficit, and debt held by the public, \$billion; deficit as \% of GNP, 1962-94

11.3 The 1997 Budget Agreement: spending outlays by functional category

12.1 US foreign aid: commitments for economic assistance by region and selected countries, 1985-93

12.2 US foreign military aid by region and selected countries, 1985-93

12.3 Defence appropriation, fiscal year 1997 


\section{Figure}

4.1 The Executive Office of the President

\section{Exhibits}

2.1 Presidents and Vice-Presidents of the United States 22

3.1 Television and US elections: the medium and the message 81

3.2 The changing political geography of the United States: how the states voted in Presidential elections, 1932-96 86

4.1 The office of the Presidency: Article II of the Constitution 100

4.2 President Clinton's Cabinet, March 1997

4.3 Expansion of the Executive Office of the President 117

$\begin{array}{ll}\text { 4.4 The power of White House staff } & 120\end{array}$

4.5 The White House bureaucracy under President Bush 123

4.6 Establishment of the Bureau of the Budget (1939) 126

5.1 Congressional research/support agency staffing 152

5.2 House and Senate Standing Committees 150

5.3 House Committee chairmen and ranking members, January 1997

5.4 Democratic and Republican House leadership in the 105th Congress

$\begin{array}{lll}\text { 5.5 } & \text { Typical cross-party Caucuses } & 171 \\ \text { 6.1 The Supreme Court and individual rights } & 186\end{array}$

6.2 Justices of the United States Supreme Court 202

7.1 Groups lobbying the Federal Government 224

8.1 Agencies and their Congressional parents 263

8.2 FAA regulations 267

8.3 The Sierra Club and the Environment Protection Agency 268

9.1 The Constitution's allocation of Federal and State powers 280

9.2 A sample of New Deal legislation bearing upon Federal-State relations

9.3 Federal grants under Presidents Truman, Eisenhower, and Kennedy

12.1 The Department of State

\section{Map}

The United States: state boundaries and major cities

xviii 


\section{Preface to the Second Edition}

My need for help has not diminished in the four years since publication of the first edition; nor, fortunately, has the propensity of my friends to supply it. Those whose generous support and advice I acknowledged in the "Preface to the First Edition", I warmly thank once more. In particular, I thank Desmond King both for his wise counsel regarding the new chapter entitled "The Politics of Cities and Suburbs", and for his generous support.

I am especially indebted to Katharine Ellis, my wife, whose love and intellectual support are essential and, happily, complete. Katharine tolerates the intrusion of American politics into her different intellectual world of nineteenth-century French cultural history with grace and understanding.

Several colleagues and students have kindly identified errors of omission, commission, or interpretation: I thank them all. I thank, too, the Principal and Fellows of St Anne's College, Oxford, and colleagues in the Politics Subfaculty at Oxford, for a happy and stimulating environment in which to work. I am much indebted to my colleagues in the PPE School (Terry O'Shaughnessy, Alison Denham, Roger Crisp, Marc Stears, Lisa Finneran, Rob McMahon, and Paul Martin) for their generous support, as I am also to those many students at St Anne's College and other colleges in Oxford who have made me think harder about numerous questions in this book's large subject. For that, and for their intellectual curiosity and enthusiasm, I am most grateful. Vincent Wright, whose observations about the probable reception of the book's first edition proved characteristically astute, has again been a perceptive critic and supportive friend; so too has David Goldey, whose unwavering encouragement and constructive criticisms are invaluable. I am also grateful to my publisher Steven Kennedy for his professionalism.

Since the publication of the First Edition, Colin Moss, a close friend of integrity and warmth with whom I often talked about American history and politics, has died. This edition is affectionately dedicated to his memory, and a proportion of royalties earned from its sale will be donated to the Cancer Research Campaign.

Responsibility for errors of fact or interpretation remains with me alone.

\section{Charlbury}

Nigel Bowles

Note: With regard to the question of the use of pronouns, I have tried to ensure that the male pronoun is used only on those occasions when the 
reference is to a man or to an office which has been held solely by men. Where the reference is to a woman, I use the female pronoun, and where it is made to an office which has been held both by men and women, the phase "he or she" or "she or he" is used. 


\section{Preface to the First Edition and Acknowledgements}

Shortly before the publication of his own textbook, my former supervisor directed me in colourful terms never to agree to write one of my own. Textbooks, he insisted, were regarded by colleagues who had written one of their own as unwelcome competition; by those who had not, as intrinsically unscholarly; and by students, degradingly and dispiritingly, as cribs. Many years later, a senior colleague asked me to write a textbook on United States government. Recalling the warning which I had received some years before from my supervisor, I demurred, but the pugnacious reply suggested that it would be unwise to decline. I warmly acknowledge my great debt to Vincent Wright, editor of the series in which this book appears, former supervisor, unembarrassed purveyor of conflicting advice, friend, and colleague. Without his early warning about the pitfalls of writing a textbook, I should have enjoyed his invitation to write it less than I did. Without his steady guidance and patience over the four years that the book has taken to complete, it would not have appeared. Without his unstinting intellectual support, it would be more deeply flawed than it is.

I am also greatly indebted to Katharine Ellis, David Goldey and Desmond King for their intellectual support, friendship, and many kindnesses. All three read the entire text, and the final draft was immeasurably improved by their critical but constructive observations. Desmond generously read several chapters in more than one draft, for which I am particularly grateful. Alan Ware read the full second draft, and made many helpful suggestions; I thank him most warmly, as I do Malcolm Anderson, Roger Crisp, Ruth Deech, and Michael Hart, each of whom read individual chapters. I also thank Herb Alexander for his assistance with campaign finance data. I am also grateful to other colleagues in the Sub-faculty of Politics at Oxford, especially Tim Hames, Gillian Peele, and Byron Shafer, for the intellectual stimulation of their company and conversation. I also thank Mark Habeeb and Richard Hodder-Williams, from whose writings and conversation on American politics over many years I have gained greatly. Warm thanks are also due to Steven Kennedy at the publishers for his professionalism and patience.

Undergraduate and postgraduate students with whom I have worked at Edinburgh and Oxford, especially Mark Brough, Gareth Davies, Chris Howard, and Robert Singh, have helped considerably in clarifying for me some of the questions addressed in this book. I am very grateful to them. 
Most of the work for the book was undertaken at Oxford in the libraries of Rhodes House, St Anne's College, and the Law Faculty Library; my thanks are due to the staff of all three libraries, especially to Alan Bell and David Smith, for their kindness and professionalism. I am grateful to the Principal and Fellows of St Anne's College, Oxford, for creating a supportive and stimulating environment in which to read, think and write. In particular, I express my warm thanks to my colleagues in the PPE School, Gabriele Taylor and Terry O'Shaughnessy, for their support. Terry drew my attention to Keynes's note of a conversation with President Roosevelt in 1941; I thank him for it.

Thanks are due to many others but there is space to mention just two. Both, sadly, have departed: Tony Allt, who first introduced me to American political history, and Philip Williams, whose knowledge and understanding of this vast subject were profound, and whose enthusiasm for it was inspirational.

Responsibility for errors of fact or interpretation is mine alone.

Charlbury

Nigel Bowles

Every effort has been made to contact all copyright-holders, but if any have been inadvertently omitted the publisher will be pleased to make the necessary arrangement at the earliest opportunity. 
"The other main criticism ... relates to the organs of government. To the outsider it looks almost incredibly inefficient. One wonders how decisions are ever reached at all. There is no clear hierarchy of authority. The different departments of the Government criticise one another in public and produce rival programmes. There is perpetual internecine warfare between prominent personalities. Individuals rise and fall in general esteem with bewildering rapidity. New groupings of administrative power and influence spring up every day. Members of the so-called Cabinet make public speeches containing urgent proposals which are not agreed as Government policy ... Nothing is ever settled in principle. There is just endless debate and endless sitting around ... Suddenly some drastic, clear-cut decision is reached, by what process one cannot understand, and all the talk seems to have gone for nothing, being a fifth wheel to the coach, the ultimate decision appearing to be largely independent of the immense parlez-vous, responsible and irresponsible that had preceded it. Nothing is secret, nothing confidential. The President laughed when I said his method of deceiving the enemy was apparently to publish so much vital information that they would not have the time to read it."

(John Maynard Keynes, XXIII, 105-k, July 1941). 


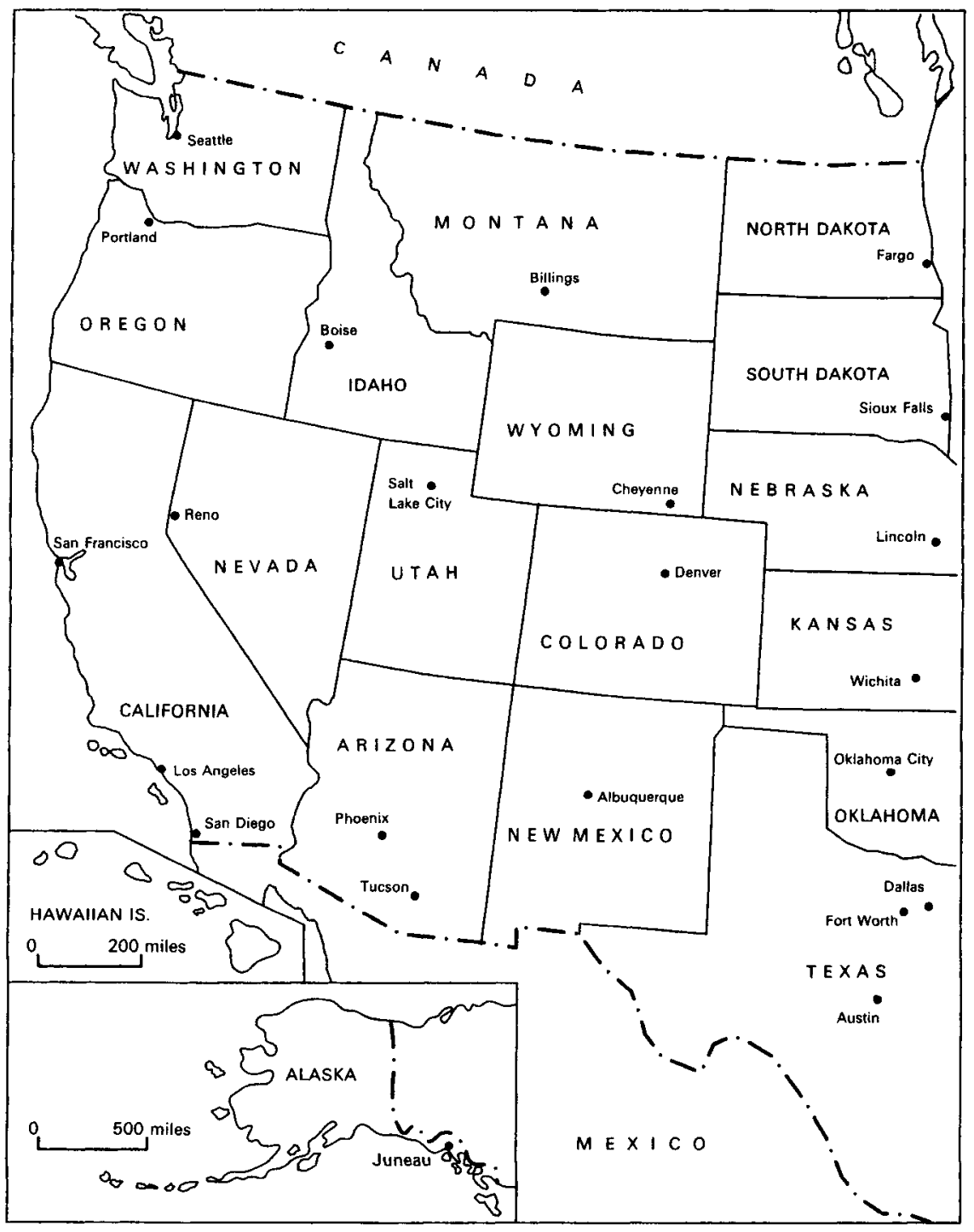

The United States: state boundaries 


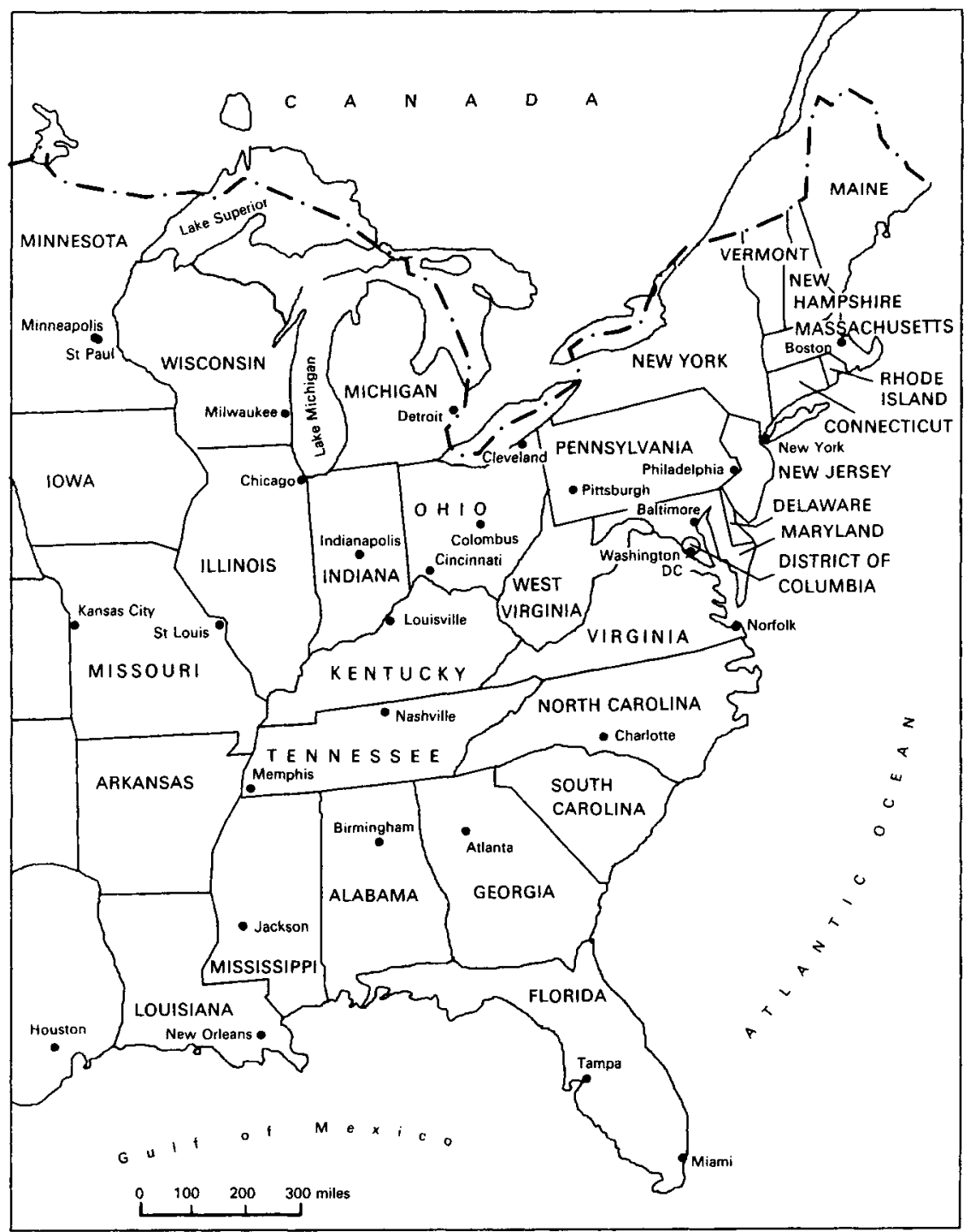

and major cities 